\title{
Greenhouse and field assessment of biological and chemical agents against guava decline
}

\author{
Cintia da Silva Alves $\oplus^{1}$, Renan Zappavigna Costa Starling $\oplus^{1}$, Lilian Lagen Rodrigues $\oplus^{2}$, Maria Laura Urbano

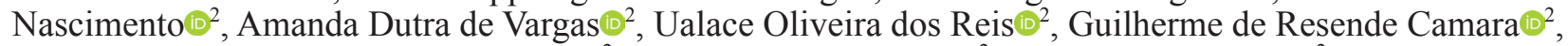

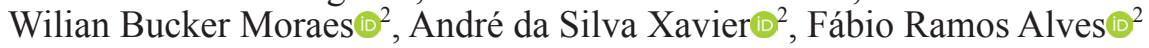

${ }^{1}$ Paulista State University (UNESP), Postgraduate Program in plant protection, Botucatu-SP. Brazil. ${ }^{2}$ Federal University of Espirito Santo (UFES), Department of Agronomy, Alegre-ES. Brazil.

Corresponding author: Fábio Ramos Alves (fabioramosalves@yahoo.com.br)

Data de chegada: 10/07/2019. Aceito para publicação em: 20/11/2020.

$10.1590 / 0100-5405 / 225806$

\section{ABSTRACT}

Alves, C.S.; Starling, R.Z.C., Rodrigues, L.L.; Nascimento, M.L.U., Vargas, A.D.; Reis, U.O.; Camara, G.R.; Moraes, W.B.; Xavier, A.S.; Alves, F.R. Greenhouse and field assessment of biological and chemical agents against guava decline. Summa Phytopathologica, v.47, n.2, p.96-102, 2021.

Guava decline is a complex disease resulting from the parasitism by Meloidogyne enterolobii $(\mathrm{Me})$, which predisposes the plant to root rot caused by Fusarium sp. Three in vitro experiments were carried out with the aim of: (i) selecting the Fluensulfone dosage capable of causing Me mortality; (ii) verifying the effect of Fluensulfone on Pochonia chlamydosporia and Trichoderma harzianum; (iii) evaluating the effect of Pochonia chlamydosporia and Trichoderma harzianum in pure doses and in association with Fluensulfone on Me mortality. Fluensulfone at $2 \mathrm{~L}^{-\mathrm{ha}^{-1}}$ had no effect on fungi. The associated and pure doses of treatments had a significant effect on $\mathrm{Me}$ mortality. A field experiment was also carried out in a guava orchard where decline occurred. The following treatments were tested: Fluensulfone; P. chlamydosporia; P. chlamydosporia + Fluensulfone; T. harzianum; T. harzianum + Fluensulfone; Carbofuran, and control. All treatments reduced $\mathrm{Me}$ population, since relative efficiency was higher than $80 \%$. Fluensulfone used alone or in combination with biological nematicides provided an increase in guava productivity. Maintaining $M e$ population low in the field is an important option for increasing productivity and reducing the losses suffered by farmers.

Keywords: Meloidogyne enterolobii, Fluensulfone, Pochonia chlamydosporia, Trichoderma harzianum

\section{RESUMO}

Alves, C.S.; Starling, R.Z.C., Rodrigues, L.L.; Nascimento, M.L.U., Vargas, A.D.; Reis, U.O.; Camara, G.R.; Moraes, W.B.; Xavier, A.S.; Alves, F.R. Avaliação no campo e em casa de vegetação de agentes biológicos e químicos contra o declínio da goiaba. Summa Phytopathologica, v.47, n.2, p.96-102, 2021.

O declínio de goiaba é uma doença complexa causada pelo parasitismo de Meloidogyne enterolobii (Me), que predispõe a planta à podridão radicular causada por Fusarium sp. Três experimentos in vitro foram realizados com os seguintes objetivos: (i) selecionar a dosagem de Fluensulfone capaz de causar mortalidade de Me; (ii) verificar o efeito da Fluensulfone sobre Pochonia chlamydosporia e Trichoderma harzianum; (iii) avaliar o efeito de Pochonia chlamydosporia e Trichoderma harzianum em doses puras e em associação com Fluensulfone na mortalidade de $M$. enterolobii. Fluensulfone na dose de $2 \mathrm{~L} \cdot \mathrm{ha}^{-1}$ não teve efeito sobre os fungos. As doses associadas e puras dos tratamentos tiveram efeito significativo na mortalidade de Me. Um experimento de campo também foi realizado em um pomar de goiaba com ocorrência de declínio. Os seguintes tratamentos foram testados: Fluensulfone; P. chlamydosporia; P. chlamydosporia + Fluensulfone; T. harzianum; T. harzianum + Fluensulfone; Carbofurano e o controle. Todos os tratamentos reduziram a população de Me, uma vez que a eficiência relativa foi superior a $80 \%$. O fluensulfone utilizado isoladamente ou em combinação com nematicidas biológicos proporcionou um aumento na produtividade de goiaba. A manutenção da baixa população de Me no campo é uma opção importante para aumentar a produtividade e reduzir as perdas sofridas pelos agricultores.

Palavras-chave: Meloidogyne enterolobii, Fluensulfone, Pochonia chlamydosporia, Trichoderma harzianum

Guava decline became established in Brazil a few years ago and has been responsible for the eradication of numerous guava orchards (7). According to Gomes et al., the symptoms of decline are attributed to the synergistic action between Meloidogyne enterolobii Yang and Eisenback, 1983 and Fusarium solani (Mart.) Sacc., and the initial parasitism of the nematode predisposes the plants to intense root degeneration by the fungus, thus making the management of this disease complex.

Management measures that reduce $M$. enterolobii population are essential to keep the plants protected against decline in the field (21). Biological control has been one of the major tools for reducing the use of synthetic nematicides (19). Among fungi with potential for agricultural use in nematode management are Pochonia chlamydosporia (Goddard) (24) and Trichoderma harzianum Rifai (13).

Another alternative for the root knot nematode management is chemical control; however, numerous synthetic nematicides have already been banned because of their high cost and high toxicity (11). The active principle Fluensulfone, or MCW-2, (5-chloro-2(3,4,4-trifluorobut-3-phenylsulfonyl) -1,3-thiazole) has nematicidal action and shows low toxicity to non-target organisms, but its effectiveness in guava decline management has not been tested yet.

Thus, the present study aimed to: i) select the Fluensulfone dosage capable of causing mortality to second-stage juveniles (J2) of $M$. enterolobii; ii) verify the effect of Fluensulfone concentrations on 
P. chlamydosporia and T. harzianum, and iii) evaluate the efficiency of the associated use of these biological and chemical agents on the management of guava decline in the field.

\section{MATERIAL AND METHODS}

Three experiments were carried out in vitro and one experiment was conducted in vivo.

\section{In vitro experiments}

These tests were carried out in the laboratory with the intention of: a) selecting the Fluensulfone dosage capable of causing mortality to second-stage juveniles (J2) of M. enterolobii; (b) verifying the effect of Fluensulfone on P. chlamydosporia and T. harzianum for later association in the field experiment; (c) evaluating the effect of P. chlamydosporia and T. harzianum, in pure doses and in association with Fluensulfone, on mortality of $M$. enterolobii $\mathrm{J} 2$.

Obtaining second-stage juveniles (J2) of M. enterolobii

A pure population of $M$. enterolobii, previously identified by isoenzyme esterase electrophoresis (3), was multiplied and maintained in the roots of guava plants (Psidium guajava L.), cv. 'Paluma', which were grown in a greenhouse. The substrate used for guava planting was composed of soil and sand at the ratio of 1:1. The soil, collected from an uncultivated site, was sieved and autoclaved for 2 hours at $140^{\circ} \mathrm{C}$, and this process was repeated three times.

Eggs $+\mathrm{J} 2$ of $M$. enterolobii were extracted from the roots according to the method of Hussey and Barker, 1973, modified by Bonetti and Ferraz (2). The concentration of the inoculum obtained in aqueous suspension was estimated in a Peters counting chamber under an inverted objective microscope. Subsequently, hatching chambers were installed and kept at $27^{\circ} \mathrm{C}$ for five days, until the number of $\mathrm{J} 2$ needed for the experiment was reached (4). J2 were collected every 24 hours.

\section{Obtaining biological and chemical nematicides}

Fluensulfone $^{\circledR}$ and the T. harzianum-based biological nematicide were purchased from Fitoclin Company, situated in Linhares, Espírito Santo State, Brazil. The P. chlamysodporia-based nematicide was obtained from Rizoflora Company, situated in Viçosa, Minas Gerais State, Brazil.

\section{Effect of Fluensulfone 40 EC on M. enterolobii mortality}

To evaluate the effect of Fluensulfone on M. enterolobii mortality, doses corresponding to $1 \mathrm{~L} \cdot \mathrm{ha}^{-1}$, 1.5 L.ha ${ }^{-1}$, 2 L.ha ${ }^{-1}$ and 4 L.ha ${ }^{-1}$ were tested, in addition to dose zero (control), as four replicates, totaling 20 sample units. Each sample unit was constituted of a 5-mL test tube, properly identified, containing 100 second-stage juveniles (J2) of $M$. enterolobii. The tubes were maintained at $27^{\circ} \mathrm{C}$ for 24 hours.

To estimate the number of immobile (inactive) individuals, the contents of each tube were poured through a $0.025 \mathrm{~mm}$ sieve. The J2 collected after sieving were washed in running water. Subsequently, J2 were again transferred to the tubes containing tap water and allowed to rest for additional 24 hours.

The percentage of mobile and immobile J2 was then visually determined under an inverted objective microscope in a Peters counting chamber. Based on the obtained data, mortality percentage was calculated according to the following equation: $\mathrm{PM}=\mathrm{NDI} \mathrm{x}$ $100 / 500$, where: $\mathrm{PM}=$ percentage of mortality; NDI $=$ number of dead individuals.

To obtain normality of error distribution, homogeneity of variances. and additive effects of variation factors, data were transformed by $\sqrt{x}$ and submitted to Cochran and Bartlett test ( $\mathrm{p} \geq 0.05)$, for homogeneity of variances, and Shapiro-Wilk ( $\mathrm{p} \geq 0.05$ ), for normality. Data were analyzed by non-linear regression.

\section{Effect of Fluensulfone 40 EC on $P$. chlamydosporia and $T$. harzianum}

The effect of Fluensulfone was assessed on M. entorolobii mortality and on the fungi $P$. chlamydosporia and T. harzianum for subsequently testing them in association (biological treatment + chemical treatment).

The experiment was carried out in a completely randomized design with 5 replicates. The fungi were previously cultured in Petri dishes and subjected to treatment with Fluensulfone, at the concentrations 2 L.ha $^{-1}$ and 4 L.ha $^{-1}(0.026 \mathrm{~mL}$ and $0.053 \mathrm{~mL})$, diluted in potatodextrose-agar (PDA) growth medium and incubated at $25 \pm 1{ }^{\circ} \mathrm{C}$ in the dark for 15 days.

After fungal growth, Petri dishes containing PDA growth medium + Fluensulfone aliquots, at $2 \mathrm{~L} \cdot \mathrm{ha}^{-1}$, were prepared based on the results of the experiment described above.

Petri dishes with $P$. chlamydosporia and $T$. harzianum discs were also prepared without the addition of Fluensulfone for control. Possible Fluensulfone toxicity on fungi was evaluated when the mycelia of both fungi reached the edge of the dish.

\section{2) In vivo experiment}

This experiment aimed to evaluate the effect of $P$. chlamydosporia and $T$. harzianum applied alone or in association with Fluensulfone on M. enterolobii $\mathrm{J} 2$ mortality and was carried out in a commercial guava orchard (cv. 'Paluma') showing natural occurrence of decline in the municipality of Pedro Canário, located in the north of Espírito Santo State, at 39 $57^{\prime} 26^{\prime \prime} \mathrm{W}$ and $18^{\circ} 17^{\prime} 33^{\prime}$ 'S, from March to December 2015. According to the international classification of Köppen, the climate in that region is of subtropical type, presenting dry winter and hot summer (Cwa), and annual average temperature of $24.0^{\circ} \mathrm{C}$.

The studied five-year old guava orchard was cultivated at $4 \times 7 \mathrm{~m}$ spacing between plants, and four planting lines were used for evaluation. Before the application of treatments, chemical and physical soil analyses were performed.

Experimental design was in randomized blocks with four replicates and subdivided plots, which were composed of seven previously tested treatments: P. chlamydosporia $2 \mathrm{~kg} \cdot \mathrm{ha}^{-1}(0.026 \mathrm{~mL})$; Fluensulfone $40 \mathrm{EC}$ 2 L.ha $^{-1}(0.026 \mathrm{~mL})$; Fluensulfone 40 EC 2 L.ha $^{-1}+$ P. chlamydosporia 2 kg.ha ${ }^{-1} ;$ T. harzianum 1 L.ha- ${ }^{-1}(0.013 \mathrm{~mL})$; Fluensulfone 40 EC 2 L.ha $^{-1}+$ T. harzianum 2 kg.ha ${ }^{-1}$; Carbofuran 0.4 L.ha $^{-1}(0.053 \mathrm{~mL})$, and control (dose zero).

Each experimental unit was composed of five plants, in a $7 \times 4$ factorial scheme, in which 7 corresponds to biological and chemical treatments/nematicides, used alone or in combination, at the recommended dosages, according to the description above, and 4 refers to the intervals of evaluation/subplot, i.e., $0,60,120$ and 180 days.

Treatment dosages were defined according to the manufacturer's recommendation and based on previous tests under laboratory conditions.

\section{Mode of application}

Treatments were applied in $1 \mathrm{~m}$ bands on each planting line after cleaning the mulch present in the planting band. 
At the beginning of treatments, the recorded average temperature was $26^{\circ} \mathrm{C}$ and the wind speed was $3.0 \mathrm{~m} / \mathrm{s}$. At the end of application, the average temperature was $25.1{ }^{\circ} \mathrm{C}$ and the wind speed was $2.9 \mathrm{~m} / \mathrm{s}$.

The volume of $6 \mathrm{~L}$ per treatment was applied with a $\mathrm{CO}_{2}$ pressurized sprayer equipped with a bar containing two fan-type nozzles, height of approximately $35 \mathrm{~cm}$, forming a $100 \mathrm{~cm}$ wide application range in the line direction.

To assist in the application, two irrigations were carried out complementary to the drip irrigation system present in the production area. The first irrigation occurred the day before treatment application, using a $10 \mathrm{~mm}$ blade, and the second irrigation was done right after spraying, at the same amount.

\section{Evaluations of $M$. enterolobii population in roots and soil}

For the evaluation of $M$. enterolobii population in the soil, four $0.5 \mathrm{~L}$ sub-samples were collected from the plant's rhizosphere region in each plot; they were homogenized, totaling samples composed of $2.0 \mathrm{~L}$ soil. In the laboratory, M. enterolobii population was extracted from the soil according to the methodology proposed by Jenkins (10), and the final nematode population (FP), composed of $\mathrm{J} 2+$ eggs of M. enterolobii, was quantified in a Peters counting chamber under an inverted objective microscope.

To assess the population in the root system, for each treatment replicate, an average of $50 \mathrm{~g}$ roots were collected from each of the three central plants. The collected root system was homogenized, totaling $150 \mathrm{~g}$ samples, which were stored in plastic bags, duly identified and packed in Styrofoam boxes until evaluations. In the laboratory, M. enterolobii population was extracted from the root system of plants based on the methodology proposed by Hussey and Barker, 1973, modified by Bonetti and Ferraz (2). The FP was quantified as previously described.

\section{Evaluation of guava fruit production}

In December 2016, coinciding with the last evaluation of $M$. enterolobii population, the average productivity of the produced guava fruits was evaluated. Fruits were harvested inside each plot and weighed on an analytical scale of $0.001 \mathrm{~g}$ accuracy. The average productivity obtained for each treatment was compared with that obtained for the control treatment (dose zero).

\section{Data analysis}

Relative Efficiency (RE) was calculated with the adapted formula of Henderson and Tilton (8), $R E=\left(1-{ }^{P} / \mathrm{T}\right) .100$, where: $\mathrm{P}=$ incidence or severity of the disease for each evaluated treatment, $\mathrm{T}$ - incidence or severity of the disease for control treatment.

Data on FP from the soil and root were transformed by $\log _{10}(x+1)$ and submitted to Cochran and Bartlett test $(\mathrm{p} \geq 0.05)$, for homogeneity of variances, and Shapiro-Wilk ( $\mathrm{p} \geq 0.05$ ), for normality.

Since subplots were repeated measures over time (days), Mauchly's test (15) was applied to verify sphericity, i.e., to verify whether the covariance matrix was similar to an identity matrix, according to that recommended by Huynh and Feldt (9), for repeated measures over time.

While data were verified for sphericity, analysis of variance was performed for the subdivided plot arrangement; the qualitative factors were submitted to means comparison test, and the quantitative factor (evaluation interval) underwent regression analysis $(\mathrm{p} \leq 0.05)$.

Significant qualitative factors were analyzed according to Tukey's test ( $\mathrm{p} \leq 0.05)$. For the analysis, $\mathrm{R}(17)$ computational application was used.

\section{RESULTS AND DISCUSSION}

\section{1) In vitro experiments}

In the in vitro experiment, the higher the applied concentration of Fluensulfone $40 \mathrm{EC}$, the higher the mortality rate of $M$. enterolobii (Figure 1). Data were fit to the nonlinear exponential model.

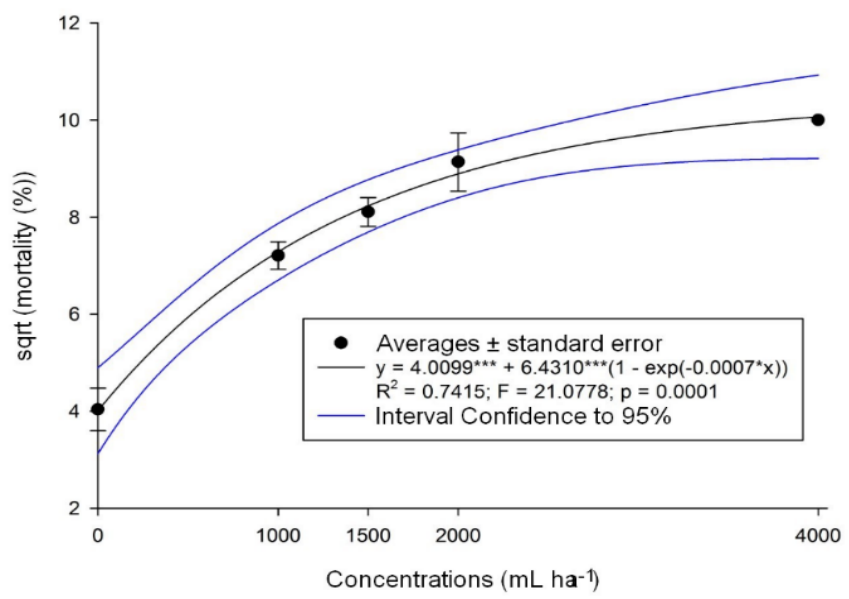

Figure 1. Average mortality of $M$. enterolobii $\mathrm{J} 2$ treated with different dosages of the synthetic nematicide Fluensulfone 40 EC under laboratory conditions. *Data transformed by $\sqrt{x}$.

The concentrations $2 \mathrm{~L} \cdot \mathrm{ha}^{-1}$ and $4 \mathrm{~L} \cdot \mathrm{ha}^{-1}$ were equally efficient.

Fluensulfone $40 \mathrm{EC}$ at 1 L.ha ${ }^{-1}, 1.5$ L.ha ${ }^{-1}, 2$ L.ha $^{-1}$ and 4 L.ha${ }^{1}$ caused $36 \%, 69 \%, 85 \%$ and $100 \%$ M. enterolobii $\mathrm{J} 2$ mortality, respectively, while $16 \%$ mortality was observed for the control. These results enabled the selection of the two doses that led to the highest nematode mortality ( 2 L.ha ${ }^{-1}$ and 4 L.ha ${ }^{-1}$ ) for the two subsequent assays.

Effect of Fluensulfone 40 EC on $P$. chlamydosporia and $T$. harzianum

Fluensulfone showed no toxicity to $P$. chlamydosporia and $T$. harzianum, at 2 L.ha ${ }^{-1}$, since the mycelial growth of both fungi in dishes with nematicide treatments was the same, compared to control.

Application of 4 L.ha ${ }^{-1}$ caused fungal death. Thus, 2 L.ha' ${ }^{-1}$ was understood as the most suitable concentration for subsequent testing both in vitro and in vivo.

Effect of $P$. chlamydosporia and T. harzianum applied alone or in combination with Fluensulfone on $\mathbf{M}$. enterolobii $\mathbf{J} 2$ mortality

After 24 hours of application, all treatments provided a high level of mortality of M. enterolobii J2, compared to control. Except for Fluensulfone $+T$. harzianum, the treatments led to an average mortality of $M$. enterolobii $\mathrm{J} 2$ that did not differ statistically from that caused by Carbofuran (positive control) (Table 1).

\section{2) In vivo experiment}

The Relative Efficiency (RE) of the analyzed treatments indicated satisfactory levels of $M$. enterolobii management, greater than $80 \%$ after 120 days (Figure 2).

Treatments based on Fluensulfone, P. chlamydosporia, Fluensulfone + P. chlamydosporia and T. harzianum showed RE superior to $90 \%$ at 120 days after application, while treatments based on Fluensulfone 
Table 1. Average mortality of second-stage juveniles (J2) of $M$. enterolobii treated with biological nematicides based on $P$. chlamydosporia and T. harzianum and the synthetic nematicide Fluensulfone $40 \mathrm{EC}$, applied alone or in association.

\begin{tabular}{ll}
\hline Treatments & Mortality (\%) \\
\hline P. chlamydosporia & $97.3 \mathrm{a}$ \\
T. harzianum & $91.0 \mathrm{a}$ \\
Fluensulfone 2L.ha ${ }^{-1}$ & $85.0 \mathrm{a}$ \\
Fluensulfone 2L.ha ${ }^{-1}+$ P. chlamydosporia & $81.3 \mathrm{a}$ \\
Fluensulfone 2L.ha ${ }^{-1}+$ T. harzianum & $66.0 \mathrm{ab}$ \\
Carbofuran & $100.0 \mathrm{a}$ \\
Control & $22.7 \mathrm{~b}$ \\
\hline CV (\%) & 18.7 \\
F & 4.5201 \\
P & 0.0094363 \\
\hline Means followed by the same letter do not differ according to Tukey's test at 5\% \\
probability. Data transformed by $\sqrt{x}$ and presented in original form.
\end{tabular}

+ T. harzianum and Carbofuran showed $90 \%$ RE at 180 days after application. At 60 days, all treatments showed RE lower than $74 \%$ (Figure 2).

The transformed data for the FP of $M$. enterolobii presented homogeneity of variances, according to Cochran and Bartlett test ( $\mathrm{p} \geq 0.05$ ), and normality, according to Shapiro-Wilk test ( $\mathrm{p} \geq 0.05$ ). Analysis of sphericity using Mauchly's test showed that both FP and number of galls $(\mathrm{NG})$ were not significant at $1 \%$ and $5 \%$, respectively ( $W_{\text {M. enterolobii }}=0.57349, \mathrm{p}=0.052334 ; W_{\text {gall }}=0.9373, \mathrm{p}=0.93735$, respectively), thus indicating data sphericity.

For the variable FP in the soil, data sphericity was also found ( $W_{\text {soil }}=0.6699, \mathrm{p}=0.16056$ ). Thus, the data were analyzed by using subplots divided in time.

Based on the analysis of variance, considering the variable FP, there was an interaction between treatments and intervals of evaluations. However, for the variable NG, the interaction was not significant (Table 2).
Table 2. Summary of the analysis of variance for the final population (FP) of roots obtained by the sum of eggs + second-stage juveniles (J2) and number of galls (NG) induced by $M$. enterolobii in roots of guava cv. 'Paluma' in a commercial area showing natural occurrence of decline in Pedro Canário, Espírito Santo State, Brazil.

\begin{tabular}{lcc}
\hline \multirow{2}{*}{ Sources of Variation } & FP & NG \\
\cline { 2 - 3 } & F & F \\
\hline Treatments (T) & 1.2626 & 0.6319 \\
Block & 1.5404 & 0.7342 \\
Time (t) & 15.9335 & 20.6545 \\
Interaction (Txt) & 1.7883 & 0.9542 \\
\hline CV1 (\%) ${ }^{1}$ & 22.72 & 60.75 \\
CV2 (\%) & 18.36 & 35.56 \\
\hline
\end{tabular}

${ }^{1}$ Coefficient of variation for the plot; ${ }^{2}$ Coefficient of variation for the subplot.

Unfolding of the factor treatment within the levels of the factor time indicated that the treatments only had an effect on the FP of $M$. enterolobii in guava roots from 120 days (Table 3), suggesting a residual action of the systemic products on the nematoid.

At 120 days, Fluensulfone applied alone or in association with P. chlamydosporia reduced FP compared to control and, at 180 days, Fluensulfone and Carbofuran were the treatments that reduced this variable (Table 3 ).

Unfolding of the factor time within the levels of the factor treatment indicated that the data fit best to the polynomial model. All treatments reduced the FP of $M$. enterolobii from 60 days on, and the best result was observed at 120 days (Figure 3 ).

Except for Carbofuran, the remaining treatments allowed a slight increase in M. enterolobii population after 120 days (Figure 3).

\section{Evaluation of guava productivity}

Fluensulfone alone or in combination with $T$. harzianum and $P$. chlamydosporia provided increased productivity, but there was no difference between each other (Figure 4).

When applied alone, Fluensulfone 40 EC showed efficiency in the management of $M$. enterolobii. This result corroborates studies
- 60 days (June)

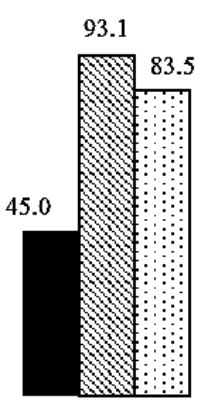

Fluensulfone (FLU)

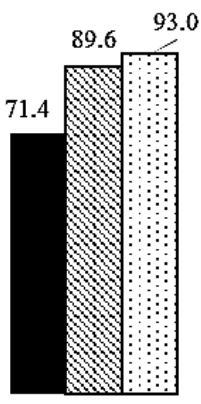

Carbofuram
120 days (August)

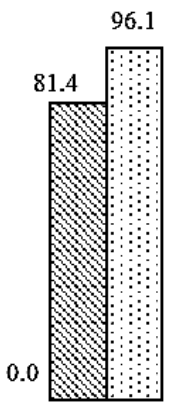

P. chlamydosporia (P. cha)

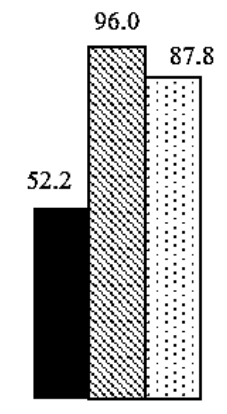

T. harzianum (T. har) $\mathbf{1} 180$ days (October)

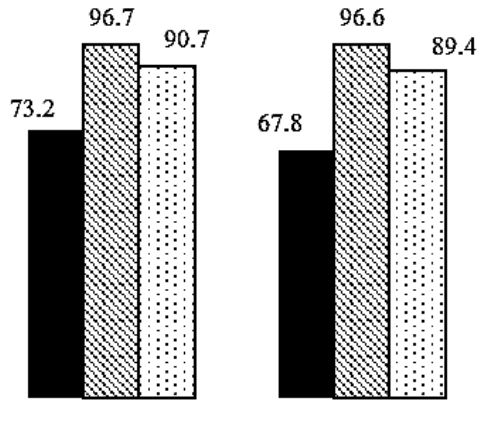

FLU + P. cha FLU + T. har

Figure 2. Relative Efficiency (RE; \%) of different treatments in the management of M. enterolobii in a field cultivated with guava cv. 'Paluma' presenting symptoms of decline in Pedro Canário, Espírito Santo State, Brazil. 
Table 3. Final population obtained by the sum of eggs $+\mathrm{J} 2$ of $M$. enterolobii extracted from roots of guava cv. 'Paluma' treated with synthetic and biological nematicides alone or in association, at different periods after application in a commercial area showing natural occurrence of decline in Pedro Canário, Espírito Santo State, Brazil.

\begin{tabular}{|c|c|c|c|c|}
\hline Treatments & \multicolumn{4}{|c|}{ Intervals (days) } \\
\hline P. chlamydosporia* & 9,750 & $1,657.5$ & $510 \mathrm{ab}$ & $2,453.3 \mathrm{ab}$ \\
\hline T. harzianum* & 8,750 & 1,115 & $442.5 \mathrm{ab}$ & $1,592.5 \mathrm{ab}$ \\
\hline Fluensulfone $+P$. chlamydosporia* & 5,000 & 930 & $432.5 \mathrm{~b}$ & $1,403.8 \mathrm{ab}$ \\
\hline Fluensulfone $+T$. harzianum $*$ & 12,750 & 990 & $1,350 \mathrm{ab}$ & $1,047.5 \mathrm{ab}$ \\
\hline Control* & 3,215 & 3,465 & $13,008.5 \mathrm{a}$ & $15,060.7 \mathrm{a}$ \\
\hline
\end{tabular}

Means followed by the same letter in the column do not differ according to Tukey's test at $5 \%$ probability; ${ }^{\text {ns }}$ Not significant according to the $\mathrm{F}$ test in the analysis of variance; *Data transformed by $\log _{10}(x+1)$ and presented in original form.
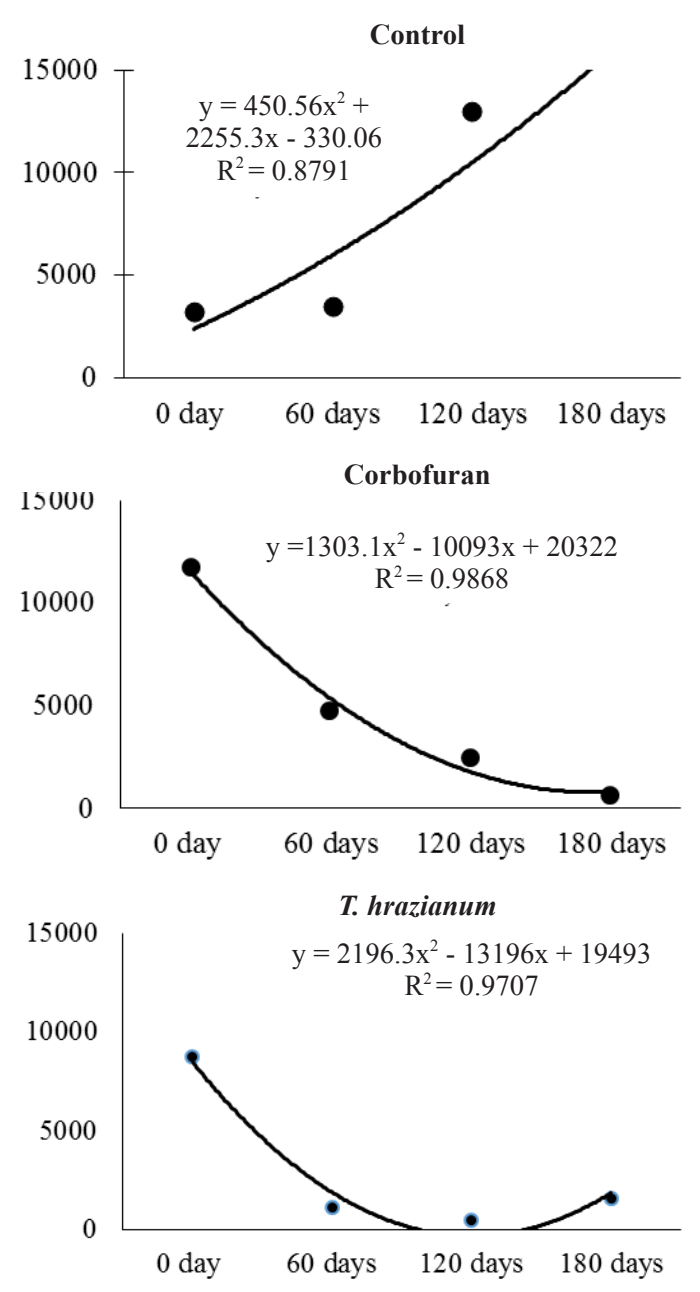
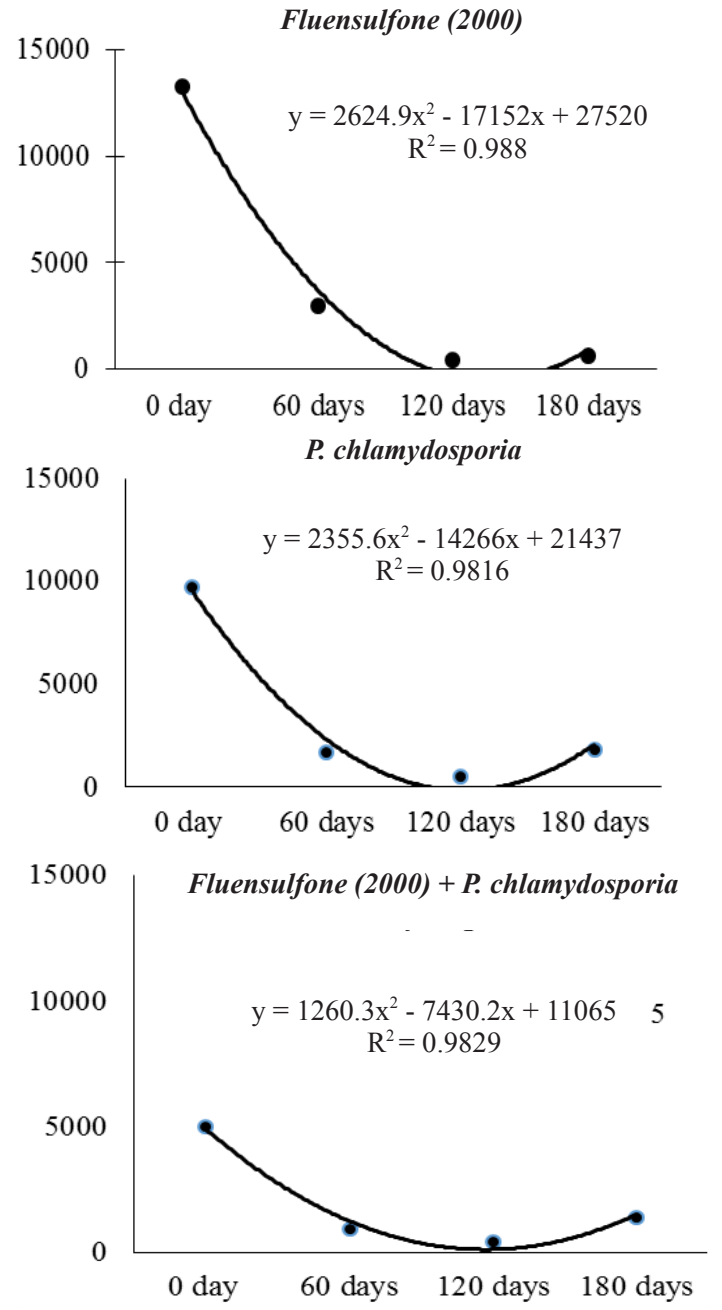

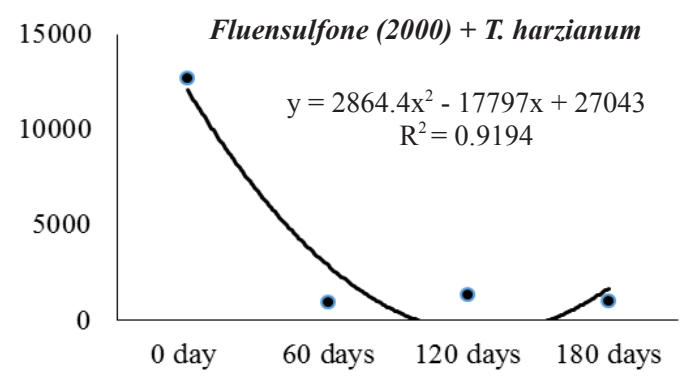

Figure 3. Final population of $M$. enterolobii (FP) obtained by the sum of $\mathrm{J} 2+$ eggs extracted from guava roots treated with Fluensulfone, Carbofuran, Pochonia chlamydosporia, Trichoderma harzianum or Fluensulfone associated with P. chlamydosporia and T. harzianum. 
Fluensulfone $+P$. chlamydosporia

Fluensulfone $+T$. harzianum

\author{
Fluensulfone
}

T. harzianum

P. chlamydosporia

Carbofuran

Control

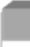
$60.0 \mathrm{a}$

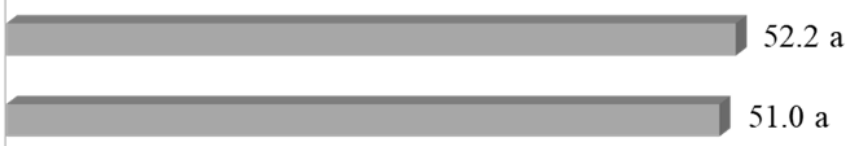

$39.7 \mathrm{~b}$

Figure 4. Average productivity, per treatment, of fruits (kg) of guava cv. 'Paluma' manifesting symptoms of decline and treated with Fluensulfone, biological nematicides based on P. chlamydosporia and T. harzianum, Carbofuran, Fluensulfone + P. chlamydosporia, Fluensulfone + T. harzianum .

demonstrating that Fluensulfone has nematicidal action and affects the nematode reproduction, development, feeding and motility (11). Fluensulfone $40 \mathrm{EC}$ has also been reported as a new and promising chemical tool for the management of plant nematodes.

Some authors have already stated that the antagonists $T$. harzianum and $P$. chlamydosporia cause reduction in the population of Meloidogyne spp. $(1,5,25)$, which may explain the present results. Meyer et al. (2000) reported that Trichoderma spp. is a notorious biological control agent for producing substances capable of inhibiting the hatching and mobility of $M$. incognita juveniles.

Compared to control, Fluensulfone applied alone or associated with $P$. chlamydosporia reduced the FP at 120 days. At 180 days, Fluensulfone and Carbofuran were most effective in reducing the FP. Reductions in the populations of $M$. incognita and $M$. exigua on coffee plants were observed at the end of 270 days after the application of synthetic nematicides (14). Meher et al. (16) demonstrated that Cadusafos persisted in the soil for around 120 days; however, this period may vary depending on the nematicide and even on the soil conditions.

Fluensulfone has low toxicity to non-target organisms and strong lethal action on eggs and adult nematodes (11), which explains the results obtained in the present experiment. Carbofuran is a systemic insecticide and nematicide used to control nematodes.

Freitas et al. (6) stated that non-fumigant nematicides, such as Carbofuran, are inhibitors of acetylcholinesterase, responsible for stimulus transmission; thus, the affected nematodes do not feed or move when under their effect (two to three months), dying from starvation. On the other hand, the action of Fluensulfone on nematodes is not accompanied by hypercontraction, which is common in nematodes that come into contact with organophosphates and carbamates (11).

All treatments, except Carbofuran, allowed a small increase in the FP after 120 days. Based on the obtained results, reapplication of these treatments is recommended, which would not cause problems to human health and the environment, since Fluensulfone presents low toxicity, and biocontrol agents are innocuous to humans and animals (25).

Fluensulfone, alone or in combination with the antagonists, caused a decrease in $M$. enterolobii population, which reflected in increased guava productivity. Siddiqui and Mahmood (20) reported that some chemical nematicides have the effect of paralyzing nematodes and exposing them to antagonists, leading these biocontrol agents to increase their efficacy, which may explain the present results.

According to several authors, some nematode antagonistic organisms are not affected by nematicides such as Aldicarb, Carbofuran,
Mirol, Forate and Oxamyl, which may enable the combined use of biological and chemical nematicides (23). Khan et al. (12) reported that the combination of Bacillus sp. with the nematicide Fertinemakil was the most effective treatment in reducing the population of $M$. javanica and improving eggplant growth.

In another study, Radwan et al. (18) noticed that several antagonistbased bioproducts, including Trichoderma sp., had their efficiency increased, due to association with the nematicide Oxamyl, in reducing both $\mathrm{J} 2$ and galls of $M$. incognita for the vegetative growth of tomato.

The positive result of $T$. harzianum in reducing nematode FP over time is justifiable since this antagonist inhibits and blocks the development of soil pathogens due to its antibiosis, parasitism and competition (1). However, the main characteristic that makes this organism a good biological control agent for Meloidogyne spp. is the production of toxic compounds (22).

Thus, T. harzianum is another option for the management of Meloidogyne spp. according to the results obtained in the present study and the characteristics that make it a good nematode control agent, which include acting in the preventive protection of plants, in the restoration of the microbial community and in the recovery of the soil structure weakened by intensive agricultural practice, besides releasing secondary metabolites that stimulate plant growth (22).

$P$. chlamydosporia, applied alone or in association with Fluensulfone, also showed a significant reduction in the FP of $M$. enterolobii during the evaluation periods, which led to increased productivity. In other studies, $P$. chlamydosporia has also been identified as an important biocontrol agent of nematodes with significant potential for different cultures. Dallemole-Giaretta et al. (5) observed that the antagonist significantly reduced the number of eggs of $M$. javanica.

This antagonist can colonize eggs in the cell multiplication and embryonic development phases more easily than juveniles; however, the effect of this antagonist may act on the suppression of females, juveniles, eggs and galls of Meloidogyne (5).

Fluensulfone $40 \mathrm{EC}$ applied alone also provided increased guava productivity. Kearn et al. (11) found a positive effect of Fluensulfone on M. incognita and M. javanica population reduction and suggested that this nematicide molecule is a promising new strategy for plant nematode management.

Maintaining a low population of $M$. enterolobii in the field, through the management alternatives presented here, is an important option for increasing the productivity and reducing the losses suffered by farmers. 


\section{ACKNOWLEDGEMENT}

The authors would like to thank the Research, Teaching and Extension Support Foundation (FINEP) and Espírito Santo Research and Innovation Support Foundation (FAPES) for financial support and the Nucleus of Scientific and Technological Development in Phytosanitary Management of Pests and Diseases (NUDEMAFI), Federal University of Espírito Santo (UFES), for support in the research development.

\section{REFERENCES}

1. Benitez, T.; Rincón, A.M.; Limón, M.C.; Codón. A.C. Biocontrol mechanisms of Trichoderma strains. International Microbiology, Barcelona, v.7, n.4, p.249-260, 2004.

2. Bonetti, J.I.S.; Ferraz, S. Modificações do método de Hussey\& Barker para extração de ovos de Meloidogyne exigua em raízes de cafeeiro. Fitopatologia Brasileira, Brasilia, v.6, n.3, p.553, 1981.

3. Carneiro, R.D.G.; Almeida, M.R.A. Técnica de eletroforese usada no estudo deenzimas dos nematoides de galhas para identificação de espécies. Nematologia Brasileira, Brasilia, v.25, n.1, p.35-44, 2001.

4. Cliff, G.M.; Hirschmann, H. Evaluation of morphological variability in Meloidogyne arenaria. Journal of Nematology, Raleigh, 17, n.4, p. 445-459, 1985.

5. Dallemole-Giaretta, R.; Freitas, L.G.; Ferraz, S.; Neves, W.S.; Coutinho, M.M. Efeito da Concentração de Clamidósporos de Pochonia chlamydosporia var. chlamydosporia no Controle de Meloidogyne javanica. Nematologia Brasileira, Piracicaba, v.32, n.4, p. 327-332, 2008.

6. Freitas, L.G.; Oliveira, R.D.L.; Ferraz, S. Introdução à Nematologia: caderno didático, $\mathrm{n}^{\circ}$ 58, Viçosa: Editora UFV. 2008, 84pp.

7. Gomes, V.M.; Souza, R.M.; Mussi-Dias, V.; Silveira, S.F; Dolinski, C. Guava Decline: A Complex Disease involving Meloidogyne mayaguensis and Fusarium solani. Journal of Phytopathology, Berlin, v.159, n.1, p.45-50, 2011.

8. Henderson, C.F.; Tilton, E.W. Tests with acaricides against the brown wheat mite. Journal of Economic Entomology, Oxford, v.48, p.157-161, 1955.

9. Huynh, H.; Feldt, L.S. Conditions under which mean square rations in repeated measurements designs have exact F-distributions. Journal of the American Statistical Association, Londres, v.65, n.332, p.1582-1589, 1970.

10. Jenkins, W.R. A rapid centrifugal - flotationtechnique for separating nematodes from soil. Plant Diasease Report, Whashington, v.48, n.1, p.692, 1964.

11. Kearn, J.; Ludlow, E.; Dillon, J.; O’Connor, V.; Holden-Dye, L. Fluensulfone is a nematicide with a mode of action distinct from anticholinesterases and macrocyclic lactones. Pesticide Biochemistry and Physiology, San Diego, v. 109, p. 44-57, 2014.

12. Khan, M.Q.; Abbasi, M.W.; Zaki, M.J.; Khan., D. Control of root-knot nematodes and amelioration of egg plant growth by the combined use of Bacillus thuringiensis berliner and nematicides. FUUAST Journal of Biology, Karachi, v.1, n.2, p.83-86, 2011.
13. Lorito, M.; Woo, S.L. Trichoderma: a multi-purpose tool for integrated pest management. in: Lutenberg, B. Principles of Plant-Microbe Interactions, Springer International Publishing, Berlim, 2015, chapter 36, p.345-353,

14. Marcuzzo, K.V.; Santos, M.A.D.; Juliatti, F.C.; Melo, B.D.; Severino, G.M. Uso de nematicidas no controle de Meloidogyne incognita e M. exigua em cafeeiro, no município de indianópolis, MG. Anais do Simpósio de Pesquisa dos cafés do Brasil, Brasília, Embrapa Café, v.1, pp. 260-261, 2000.

15. Mauchly, J.W. Significance Test for Sphericityof a Normal n-Variate Distribution. The Annals of Mathematical Statistics, Beachwoodv, 11, n.2, p.204-209, v.1940.

16. Meher, H.C.; Cajbhiye, V.T.; Singh, G., Kamra, A.; and Chawla, G. Persistence and nematicidal efficacy of Carbosulfan, Cadusafos, Phorate and Triazophos in soil and uptake by chickpea and tomato crops under tropical conditions. Journal of Agricultural Food and Chemistry, Washington, v.58, n.3, p. 1815-1822, 2010.

17. Meyer, S.L.F.; Massood, S.L.; Chitwood, D.J.; Roberts, D.P. Evaluation of Trichoderma virens and Burkholderia cepacia for antagonistic activity against root-knot nematode, Meloidogyne incognita. Nematology, Leiden, v. 2, n. 8, p. $871-879,2000$.

18. R Development Core Team. R: A Language and Environment for Statistical Computing, R Foundation for Statistical Computing. Vienna, Austria, 2009. http://www.R-project.org. Accessed on: 16 Dec. 2018.

19. Radwan, M.A.; Abu-Elamayem, M.M.; Farrag, S.A.A.; and Ahmed, N.S. Integrated management of Meloidogyne incognita infecting tomato using bio-agents mixed with either oxamyl or organic amendments. Nematologia Mediterranea, Bari, v.39, n.2, p.151-156, 2011.

20. Rodrigues, L.L.; Alves, F.R.; Chagas, E.N.; Camara, G.R.; Silva, G.A.; Jesus Jr, W.C. and Moraes, W.B. Management of Meloidogyne javanica with biological pesticides and oils in a lettuce field. Nematoda, Campos dos Goytacazes, v.3, p.01-09, 2016

21. Siddiqui, Z.A.; Mahmood, I. Role of bacteria in the management of plant parasitic nematodes: a Review. Bioresource Technology, New York, v.69, n.2, p.167-179, 1999.

22. Sousa, R.M.; Nogueira, M.S.; Lima, I.M., Melarato, M.; Dolinski, C.M. Manejo de nematoides-das-galhas da goiabeira em São João da Barra (RJ) e relato de novos hospedeiros. Nematologia Brasileira, Brasilia, v.30, n.2, p.165-169, 2006.

23. Spiegel, Y.; Chet, I. Evaluation of Trichoderma spp. as a biocontrole agent against soilborne fungi and plant-parasitic nematodes in Israel. Integrated Pest Management Reviews, Oxford, v.3, n.3, p.169-175, 1998.

24. Tzortzakakis, E.A.; Gowen, S.R. Evaluation of Pasteuria penetrans alone and in combination with oxamyl, plant resistance and solarization for control of Meloidogyne spp. on vegetables grown in greenhouses in Crete. Crop Protection, Lincoln, v.13, n.6, p.455-462, 1994.

25. Viggiano, J.R.; Freitas, L.G.; Lopes, E.A. Use of Pochonia chlamydosporia to control Meloidogyne javanica in cucumber. Biological Control, Sophia Antipolis, v. 69, p.72-77, 2014.

26. Zinger F.D. Estratégias de manejo de Meloidogyne incognita raça 1 em cafeeiro conilon. 2015. 66f. Tese - (Doutorado em Produção Vegetal / Fitossanidade), Universidade Federal do Espírito Santo, Alegre, ES. 